\title{
PENYULUHAN BANGUNAN TAHAN GEMPA Dan METODE PERBAIKAN BANGUNAN AKIBAT GEMPA DI PULAU LOMBOK
}

\section{Counseling For Earthquake Resistant Buildings And Methods For Improving Buildings Due To Earthquake In Lombok Island}

\author{
Fathmah $^{1}$, Hariyadi ${ }^{1}$, Merdana $^{1}$, Kencanawati $^{1}$, Nurahmah $^{2}$ \\ ${ }^{1}$ Teknik Sipil Universitas Mataram, ${ }^{2}$ Jurusan Tekhnik Sipil niversitas Negeri Malang \\ Jalan Majapahit Nomor 62 Kota Mataram Provinsi NTB \\ *Alamat korespondensi : fathmah_mahmud@unram.ac.id \\ (Tanggal Submission: 6 July 2020, Tanggal Accepted: 28 Desember 2020)
}

\begin{abstract}
ABSTRAK
Pulau Lombok berada dekat dengan pertemuan dua lempeng besar yaitu Lempeng Hindia-Australia di bagian selatan dan lempeng Eurasia dibagian utara, serta terdapat Sesar Naik Flores yang sangat aktif, pada tahun 2018 terjadi beberapa gempa besar besar dimulai 26 Juli 2018 sebesar 6,4SR, 7SR 5 Agustus 2018, 6,2SR tanggal 9 Agustus 2019, 6,9 SR 19 Agustus 2018. Rentetan gempa bumi ini merupakan gempa transform dari Back Arc Trusht Flores yang dangkal sehingga daya rusak sangat besar. Dari rentetan gempa ini diketahui total korban jiwa mencapai 564 orang, jumlah rumah rusak mencapai 167.000 , dan ribuan fasilitas umum lainnya. Kegiatan pengabdian kepada masyarakat ini bertujuan memberikan pengetahuan tentang struktur bangunan tahan gempa, pola bangunan, tata letak bangunan, bahan bangunan dari beton, stek dari kolom ke dinding, stek dari pondasi ke sloof, bahan bangunan kayu diantaranya cara penyambungan dari baut dan paku cara takikannya, penyokongnya. Begitu juga dalam perbaikan memberikan pengetahuan metode yang cepat tidak perlu pengawasan yang berlebihan, bahan lokal yang murah. Pengabdian ini dinyatakan berhasil ditinjau dari aspek afektif dan kognitif, peserta penyuluhan telah memahami pentingnya bangunan tahan gempa. Sedangkan dari aspek psikomotorik, Tim Penyuluh belum dapat memantau perubahan perilaku terhadap sistem perencanaan bangunan tahan gempa yang terjadi pada peserta penyuluhan, mengingat terbatasnya waktu dan minimnya dana penyuluhan. Masyarakat kurang memiliki motivasi karena kurangnya keahlian dalam teknik perencanaan pembangunan tahan gempa dan kurang teraturnya sector pembangunan. Untuk itu perlu dilakukan pemantauan yang berlanjut dan berkesinambungan.
\end{abstract}

Kata Kunci : Bangunan, perbaikan, tahan gempa, Lombok 


\section{PENDAHULUAN}

Gempa adalah getaran bumi yang terasa dipermukaan, akibat terjadinya pelepasan energi yang cepat, karena adanya pergeseran kerak bumi. Di Indonesia sering terjadi gempa karena terletak diantara tiga lempeng besar lapisan bumi yaitu Eurasian plate, Indo-Australian Plate dan Pacific plate serta Sembilan plat kecil kecil diantaranya sunda plate, sahul plate. Dan puluhan fault, back arc dan subduction disepanjang negara kepulauan Indonesia.

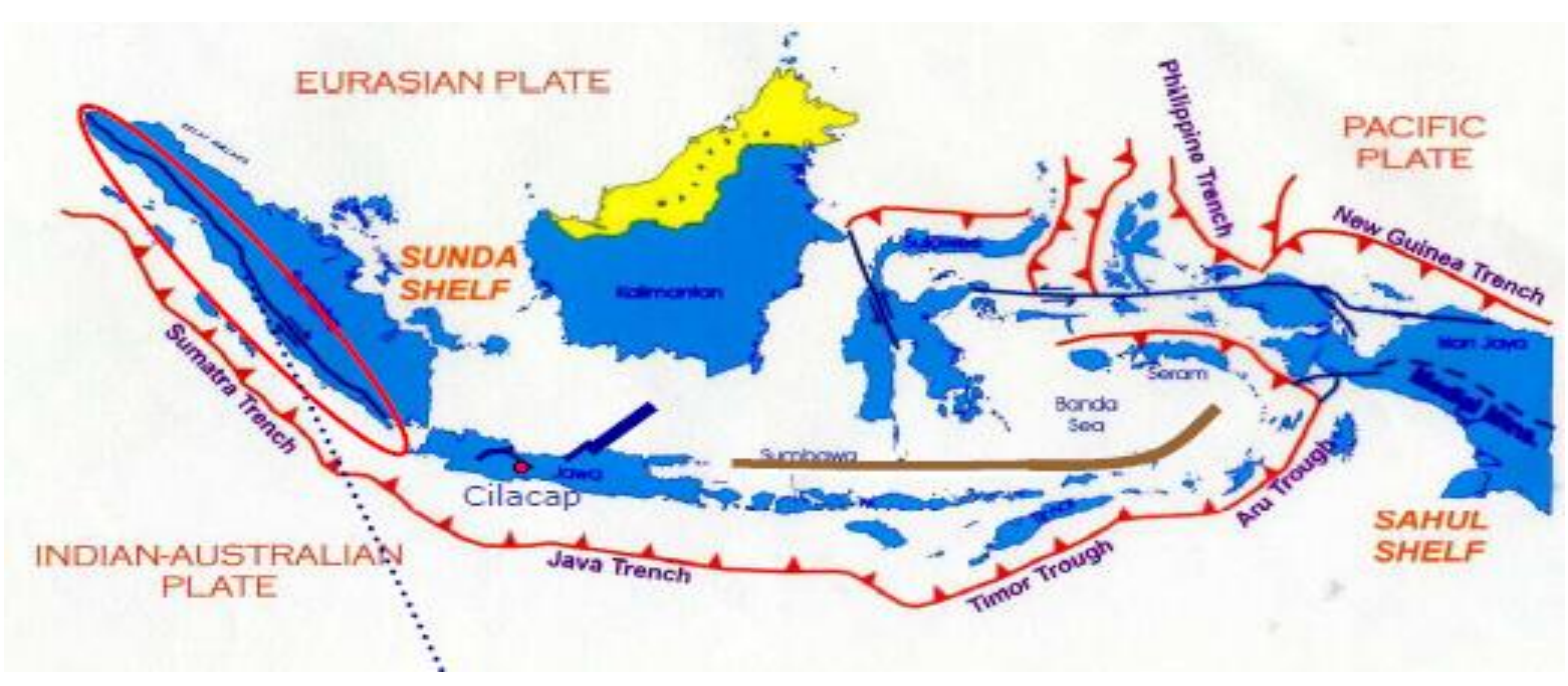

Gambar 1. Plate Tektonik di Indonesia (Irsyam,2009)

Terdapat tiga perbatasan dan pergerakan lempeng pada teori pelat tektonik yaitu;

1. Divergent dua lempeng saling menjauh, biasanya terjadi didasar laut gempa yang dihasilkan relative kecil.

2. Convergent dua lempeng saling mendekat, biasanya gempa yang dihasilkan relative besar, karena adanya penumpukan tegangan yang besar sebelum terjadi kehancuran contohnya subduction Eurasian plate dengan Indo-Australian Plate yang berada disebelah selatan Indonesia dari ujung barat sampai timur Idonesia.

3. Transform pergeseran dua lempang, akibat pergeseran ini terjadi peregangan yang cukup besar, biasa dekat permukaan atau gempa dangkal sehingga daya rusak sangat besar
Gempa bumi sering sekali terjadi di pulau Lombok ini karena pulau Lombok berada dekat dengan pertemuan dua lempeng besar yaitu Lempeng Hindia-Australia di bagian selatan dan lempeng Eurasia dibagian utara. Dan terdapat sesar Sesar Naik Flores atau Flores Back Arc Thrust yang sangat aktif, pada tahun 2018 terjadi beberapa gempa besar besar dimulai 26 Juli 2018 sebesar 6,4SR, 7SR 5 Agustus 2018, 6,2SR tanggal 9 Agustus 2019, 6,9 SR 19 Agustus 2018 dengan ribuan gempa susulan. Rentetan gempa bumi ini merupakan gempa transform dari Back Arc Trusht Flores dengan kedalaman $10 \mathrm{~km}$, menurut Gunawan (2001) gempa kedalaman $70 \mathrm{~km}$ atau kurang termasuk gempa dangkal, sehingga daya rusak sangat besar, pada Gambar 2 diberikan titik titik pusat gempa yang terjadi pada tahun 2018. 


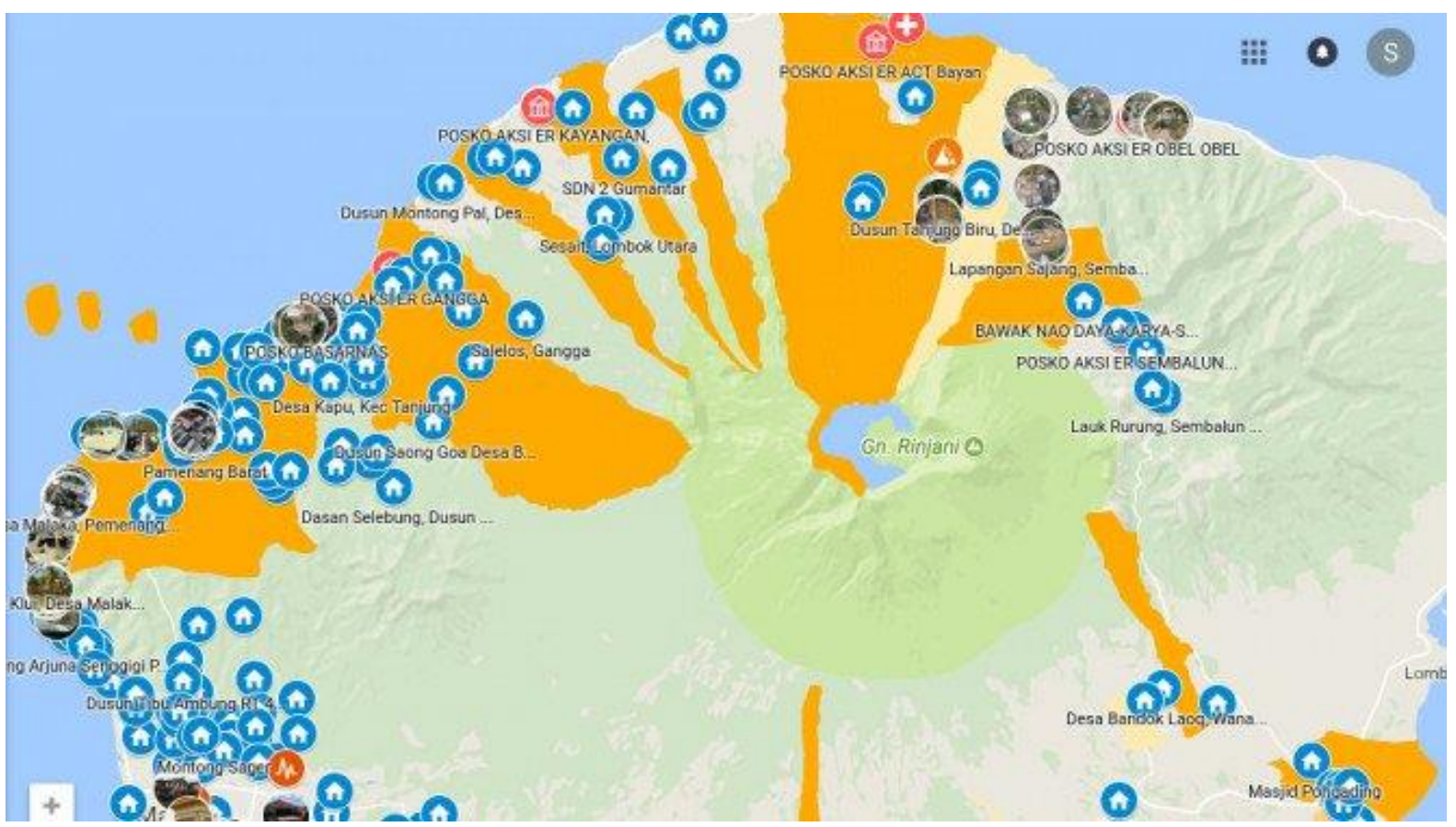

Gambar 2. Pusat Gempa Bumi di Pulau Lombok pada Juli-Agustus 2018.

Dari data Badan Nasional Penanggulangan Bencana atau BNPB, bencana gempa Lombok di sepanjang Agustus 2018, telah diketahui berapa banyak korban jiwa, rumah yang hancur, fasilitas publik yang rusak, hingga kebutuhan dana untuk merehabilitasi dan merekonstruksi seluruh dampak tersebut. Berdasarkan data per tanggal 10 September 2018 telah diketahui total korban jiwa mencapai 564 orang. Sedangkan jumlah rumah rusak mencapai 167.000. Karena banyaknya rumah yang rusak terdapat jumlah total pengungsi di NTB yaitu 445.343 orang yang menyebar diseluruh wilayah NTB. Di samping itu, jumlah sekolah yang rusak dan terdampak mencapai 1.194 unit dimana 53 persen atau sekitar 639 unit adalah bangunan Sekolah Dasar. Kemudian PAUD 254 unit, SMP 155 unit, SMA 72 unit, SMK 56 unit, dsn SLB 8 unit. Total kerusakan fasilitas pendidikan terbanyak terjadi kembali terjadi Lombok Utara dengan 294 unit sekolah. Fasilitas kesehatan juga luput dari kerusakan, sehingga diperoleh data sebanyak 321 fasilitas kesehatan rusak dengan 26,48 persen di antaranya berada di Lombok Barat. Sementara 35,85 persen atau sebanyak 115 unit dialami oleh Pos Kesehatan Desa atau Poskedes. Lalu ada 86 Puskesmas dan 9 rumah sakit. Demikian juga rumah ibadah, di NTB terdapat 630 unit Masjid rusak, 461 mushola, 1 gereja di Mataram, 1 Vihara di Lombok Utara, dan 50 pura. Total kerusakan masjid terbanyak ada di Lombok Timur dengan 267 unit dan pure terbanyak ada di Lombok Barat.

Melihat banyaknya bangunan rusak baik itu rusak berat, sedang dan rusak ringan dan mengingat Pulau Lombok merupakan wilayah yang rentan terhadap bencana gempa, untuk mengurangi korban jiwa dan kerusakan infrastruktur akibat bencana gempa maka sangat penting untuk dilakukan penyuluhan kepada masyarakat luas tentang struktur bangunan tahan gempa dan metode perbaikan rumah tinggal pasca gempa. Untuk merealisasikan tujuan tersebut maka dalam kegiatan ini dilakukan pengenalan teknologi struktur tahan gempa dan metode perbaikan rumah tinggal pasca gempa, dilakukan 
pengabdian dengan judul Penyuluhan Bangunan Tahan Gempa Dan Metode Perbaikan Bangunan Akibat Gempa Di Pulau Lombok.

Penyuluhan ini bertujuan memberikan kontribusi yang besar dalam meningkatkan pemahaman masyarakat tentang pentingnya bangunan tahan gempa, serta meningkatkan pengetahuan masyarakat tentang metode perbaikan rumah dan perkuatan rumah agar menjadi tahan gempa. Masyarakat memiliki kemampuan mengatur bentuk bangunan, tata letak bangunan mereka mampu merencanakan penataan bangunan yang tahan gempa sehingga tingkat keamanan bangunan lebih tinggi, masyarakat mengetahui dan terampil membangun rumah perbaikan rumah yang rusak akibat gempa.

\section{METODE KEGIATAN}

Pengabdian ini bekerjasama dengan dinas Pekerjaan Umum dan Dinas Sosial Propinsi Nusa Tenggara Barat. Sebelum melakukan pengabdian ini yang berjudul Penyuluhan Bangunan Tahan Gempa Dan Metode Perbaikan Bangunan Akibat Gempa Di Pulau Lombok dilakukan dahulu pendekatan kepada pemuka masyarakat seperti kepala desa dan aparat desa lainnya. Pada Gambar 3 terlihat poto tim pengabdian dengan instansi terkait.

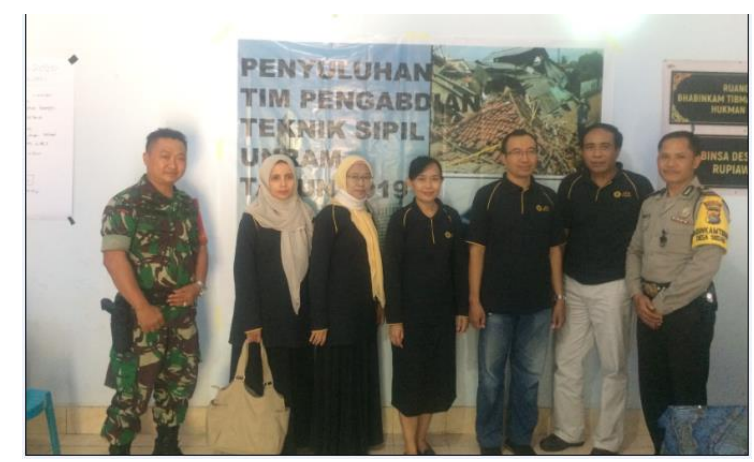

Gambar 3. Poto tim Pengabdian \& instansi terkait
Adapun langkah-langkah pengabdian dilapangan yaitu:

1. Memberikan penjelasan bagaimana membangun struktur Rumah tahan gempa menggunakan LCD kepada semua peserta, bisa dilihat pada Gambar 4 dibawah ini.

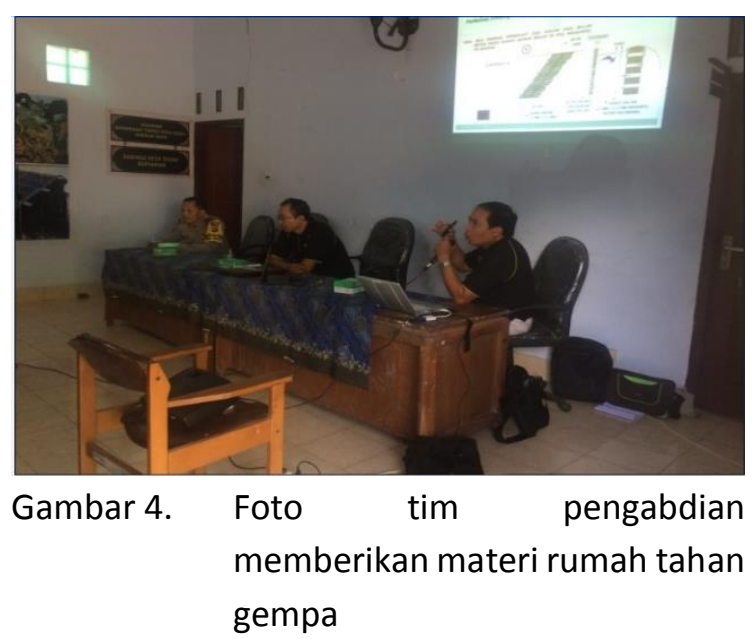

2. Memberikan pengetahuan tentang struktur bangunan tahan gempa, pola bangunan, tata letak bangunan, bahan bangunan dari beton bertulang, stek dari kolom ke dinding, stek dari pondasi ke sloof, bahan bangunan kayu diantaranya cara penyambungan dari baut dan paku cara takikannya, penyokongnya.

3. Memberikan pengetahuan tentang caracara perbaikan banguanan tahan gempa dan persyaratan dalam menentukan caracara perbaikan diantaranya:

a. Perubahan revolusioner terhadap pola konstruksi yang biasa dipakai, tidak cocok, jadi tidak praktis

b. Perubahan-perubahan terhadap pola konstruksi yang biasa dipakai harus sesederhana mungkin, yaitu yang dapat dimengerti dan ditiru oleh tukang-tukang setempat. 
c. Teknik-teknik yang diperkenalkan harus sedemikian sehingga dapat ditiru dengan mudah oleh tukang-tukang setempat dan sebagian besar pekerjaan dapat dilaksanakan dengan tanpa perlu pengawasan yang berlebihan.

d. Bahan-bahan lokal harus diutamakan pemakaiannya, bahanbahan yang sulit didapat sedapat mungkin dihindari.

e. Bahan-bahan yang akan dipakai harus bisa diperoleh dengan murah, sama murahnya seperti pada waktu membangun rumah asalnya.

f. Jumlah penambahan biaya harus praktis dapat diabaikan

4. Setelah memberikan materi dengan presentasi secara jelas dan ringkas, peserta di berikan waktu untuk bertanya bagi yang belum jelas bisa dilihat pada Gambar 5 .

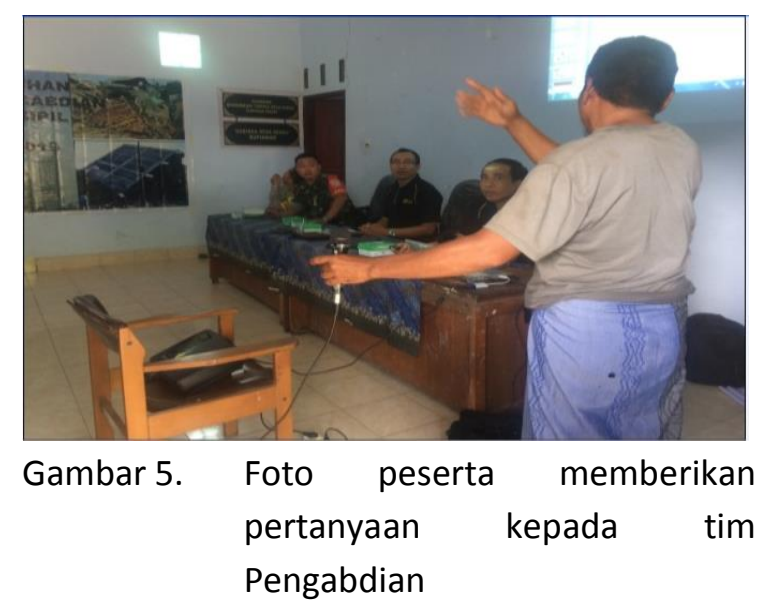

Kegiatan pengabdian ini mendukung program pemerintah percepatan rehabilitasi dan rekonstruksi bangunan rumah tinggal pasca gempa Lombok sampai saat ini masih sedang diaksanakan dan dipercepat. Apalagi ada dana bantuan stimulan dari pemerintah yaitu sebesar 50 juta untuk rusak berat, 25 juta untuk rusak sedang, dan 10 juta untuk rusak ringan. Apabila dikaji dan dikelompokkan, maka ada banyak sekali jenis kerusakan rumah tinggal. Ada kerusakan yang sifatnya struktural dan non-struktural. Sehingga metode perbaikan yang harus dilakukan juga banyak sekali jenisnya, dan memerlukan metode perbaikan yang berbeda-beda pula. Mengingat perbaikan dan rekonstruksi rumah yang terdampak gempa ini merupakan kegiatan swadaya yang dikoordinir oleh Kelompok Masyarakat (Pokmas), maka penyuluhan tentang metode perbaikan rumah yang tepat kepada masyarakat sangat penting untuk dilakukan. Agar rumah hasil perbaikan tersebut selain menjadi baik dan layak huni kembali, juga menjadi rumah tahan gempa.

Pengabdian ini yang berjudul Penyuluhan Tentang Bangunan Tahan Gempa Dan Perbaikan Bangunan Akibat Gempa Di Pulau Lombok penyuluhan dilaksanakan pada hari Selasa, tanggal 3 September 2019, Bertempat di Kantor desa Sedau dan desa Gelora, kecamatan Narmada, Kabupaten Lombok Barat, dan desa Gelora Kecamatan Sikur Kabupaten Lombok Timur dengan jumlah peserta yang cukup banyak diatas target yang disiapkan, bisa dilihat pada Gambar 6 dibawah ini.

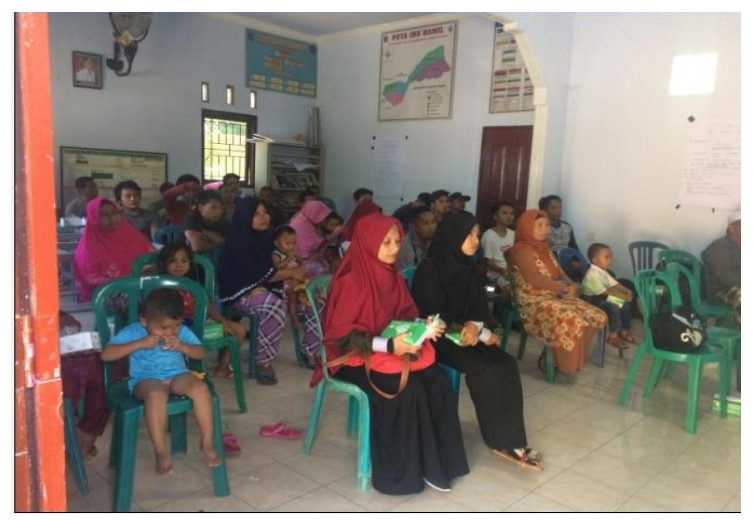

Gambar 6. Foto peserta Pengabdian

Adapun beberapa pertimbangan pemilihan lokasi ini adalah : 
1. Adanya mahasisawa KKN yang berlokasi desa Sedau, kecamatan Narmada, Kabupaten Lombok Barat, dan desa Gelora Kecamatan Sikur Kabupaten Lombok Timur, yang mempasilitasi atau motor penggerak pengabdian ini menghubungkan tim pengabdian dengan warga desa, aparat desa dan pemua masyarakat

2. Sebagai suatu daerah pedesaan, mayoritas penduduk Desa Sedau dan Gelora tergolong masyarakat berpenghasilan rendah yang mempengaruhi kemampuan masyarakat menyediakan perumahan yang layak dari syarat teknis.

3. Tingkat pendidikan penduduk relatif rendah, sehingga mengakibatkan rendahnya kesadaran penduduk akan pentingnya rumah tahan gempa.

4. Pada lokasi perkampungan, kepadatan penduduknya tinggi dan perumahan yang dibangun belum permanen dan mudah rusak akibat gempa.

\section{HASIL DAN PEMBAHASAN}

Pada umumnya pengabdian ini yang mengambil lokasi di Desa Sedau Kecamatan Narmada Kabupaten Lombok Barat serta desa Gelora Kabupaten Lombok Timur Propinsi Nusa Tenggara Barat, berjalan lancar sesuai dengan yang diinginkan tetapi ada beberapa kendala diantaranya luasnya daerah yang harus

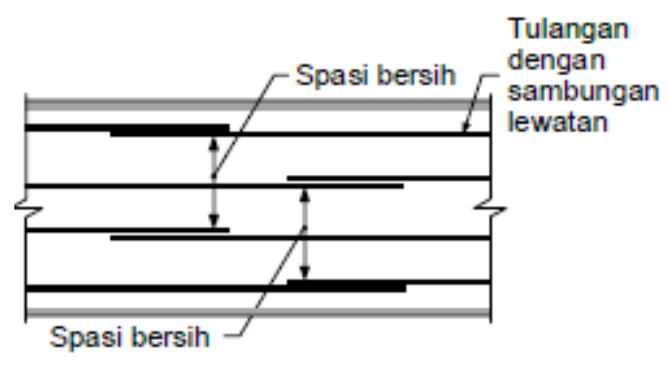

dijelajah untuk sosialisasi, jumlah dusun yang harus dijangkau sangat banyak dan kurangnya dana.

Sistem evaluasi dilaksanakan dengan melihat peran serta masyarakat dalam mengikuti kegiatan penyuluhan. Dengan disampaikannya materi mengenai perencanaan rumah tahan gempa pada saat penyuluhan, diharapkan pengabdian berlanjut, dikarenakan tertariknya masyarakat pada beberapa alternatif pembangunan rumah sederhana tahan gempa. Disamping itu, masyarakat juga tertarik tentang metode mitigasi bencana apabila terjadi gempa.

Dari aspek afektif dan kognitif, peserta penyuluhan telah memahami pentingnya bangunan tahan gempa. Sedangkan dari aspek psikomotorik, Tim Penyuluh belum dapat memantau perubahan perilaku terhadap sistem perencanaan rumah tinggal sederhana tahan gempa yang terjadi pada peserta penyuluhan, mengingat terbatasnya waktu dan minimnya dana penyuluhan, untuk itu perlu dilakukan pemantauan yang berlanjut dan berkesinambungan. Untuk keperluan tersebut, Tim Penyuluh menyatakan kesediaannya untuk didatangi masyarakat yang membutuhkan informasi lebih lanjut mengenai perencanaan rumah sederhana tahan gempa Ada beberapa teori mengenai bangunan tahan gempa yang perlu di ketahui lebih detail, antara lain :

1. Panjang penyaluran/sambungan lewatan (Gambar 7) 
Gambar 7. Spasi bersih tulangan sambungan lewatan untuk menentukan nilai $\ell$ d untuk sambungan lewatan selang-seling (staggered) dan sabungan lewatan, SNI 2847(2019)

2. Detail kolom pondasi pada baik menggunakan kayu maupun beton
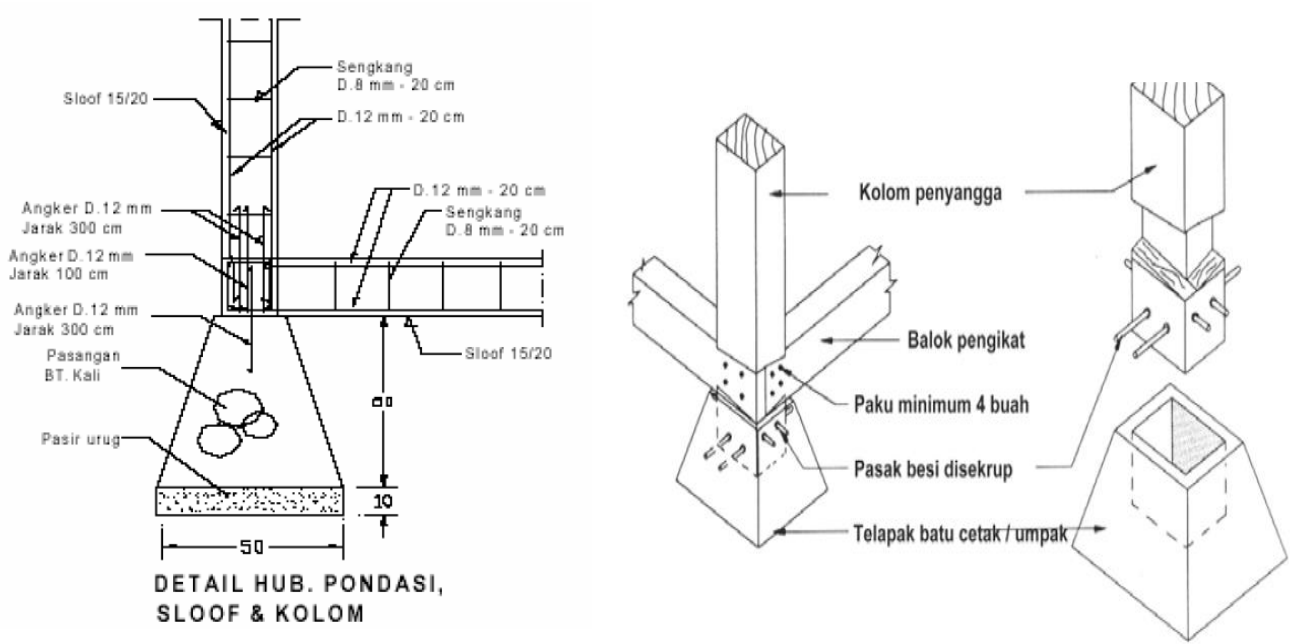

Gambar 8 Hubungan kolom pondasi

3. Cara Pembuatan sengkang

Mander, J.B., Priesly, M.J.N, Park, R (1988) menjelaskan kurva tegangan regangan meningkatkan kekuatan nomimal akibat pengekangan. Dalam Purwono (2007) Kolom Beton yang merupakan bagian sistem penahan gaya lateral harus dihubungkan untuk menstranfer gaya angkat dan geser ke fondasi.
Ketidak beradaan hubungan yang kuat antara kolom dan fondasi dapat mengakibatkan kolom terangkat atau bergeserdari pendukung tumpuannya. Saatcioglu, Ozcebe (1986) daktilitas kolom dipengaruhi konfigurasi pengekangan. Menurut Gideon, K (1993) Sengkang sengkang pada balok dan kolom harus dilengkapi kait miring

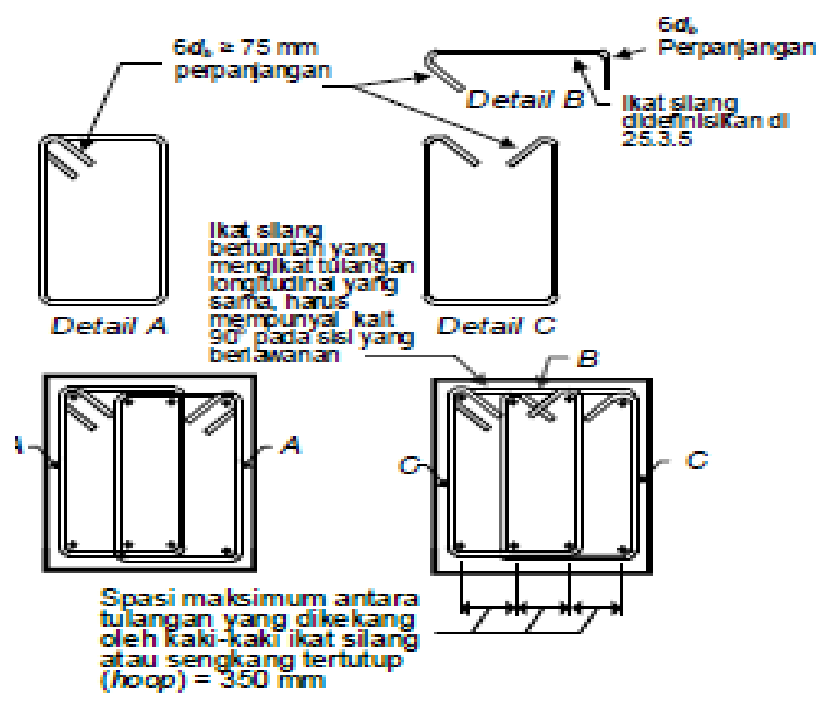


Gambar 9. Sengkang tertutup (hoop) dan ilustrasi batasan maksimum spasi horizontal penumpu batang longitudinal,Purwono (2005)

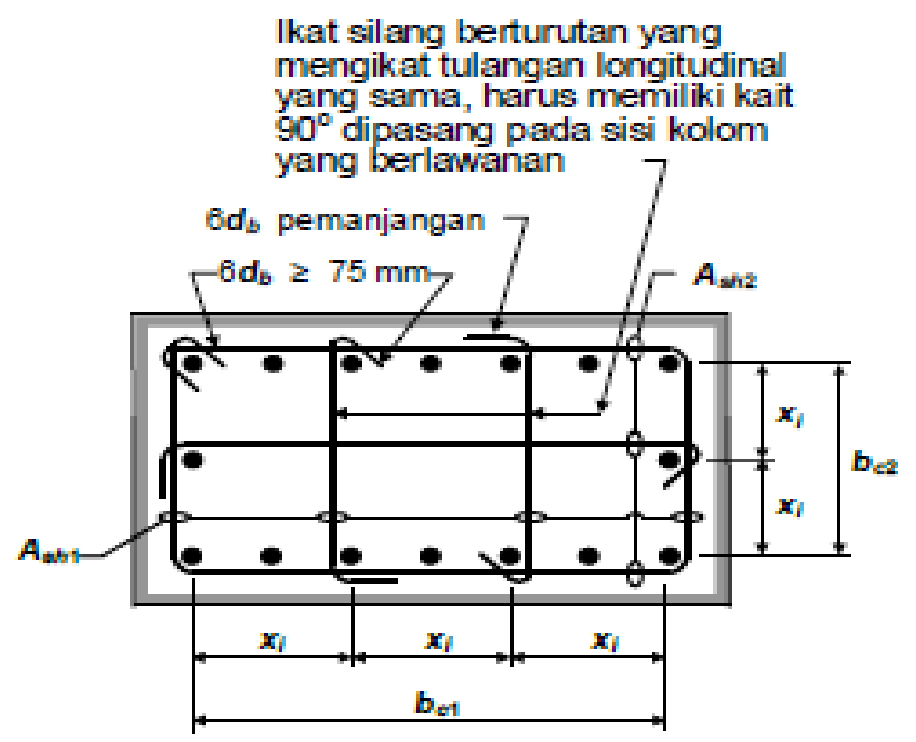

Gambar 10. Penulangan transversal pada kolom SNI 2847 (2019)

Menurut Direktorat Cipta Karya (2006) dengah bangunan yang tidak simetris, denah bangunan harus dipisah sebagaimana bangunan jadi simetris. Dalam Tedy (2016) yang disarankan dilakukan pemisahan atau dilatasi pada tiap bentuk
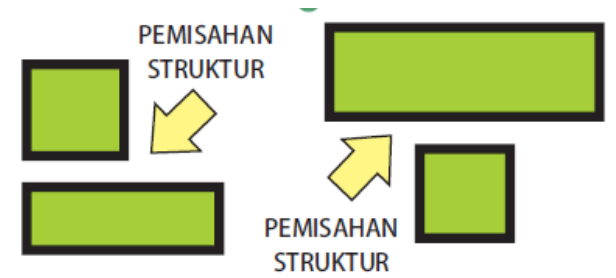

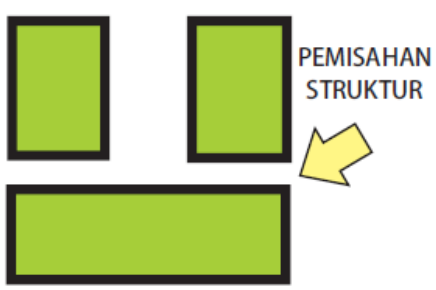

Gambar 11. Pola Denah bangunan, Tedy,B (2010)

Dalam Direktorat Cipta Karya (2006) Bahan Persyaratan bahan beton seperti air, pasir dan kerikil harus mengikuti PUBI-1982, pondasi yang digunakan pondasi setempat dari pasangan batu kali dengan campuran adukan 1 PC : 5 pasir. Pada dasar pondasi harus diberi lapisan pasir urug tebal padat $10 \mathrm{~cm}$. Permukaan lantai dan bagian-bagian luar pondasi yang tampak diratakan dengan adukan 1 PC : 3 pasir, setebal minimum $5 \mathrm{~mm}$ dan di atasnya diberi saus semen sebagai penghalus. Untuk dinding kamar mandi harus diplester dengan adukan campuran 1 PC : 2 pasir, setinggi
1,5 m dari muka lantai. Mutu beton yang disyaratkan dalam pekerjaan ini adalah mutu beton K-125 atau dengan campuran nominal 1 PC : 2 Pasir : 3 Kerikil (dalam perbandingan isi). Slump pada saat pengerjaan masimum $7,5 \mathrm{~cm}$ dan minimum $2,5 \mathrm{~cm}$. Pada arah pertumbuhan, besi beton sloof disediakan panjang penyaluran sepanjang $60 \mathrm{~cm}$ dan dibungkus dengan adukan dari campuran 1 Pc : 10 Psr dengan dimensi yang sama dengan dimensi sloof.

Ada beberapa cara perbaikan bangunan rusak akibat gempa diantaranya 
- Perbaikan kolom yang rusak dengan

- Perbaikan dinding yang retak jacketing

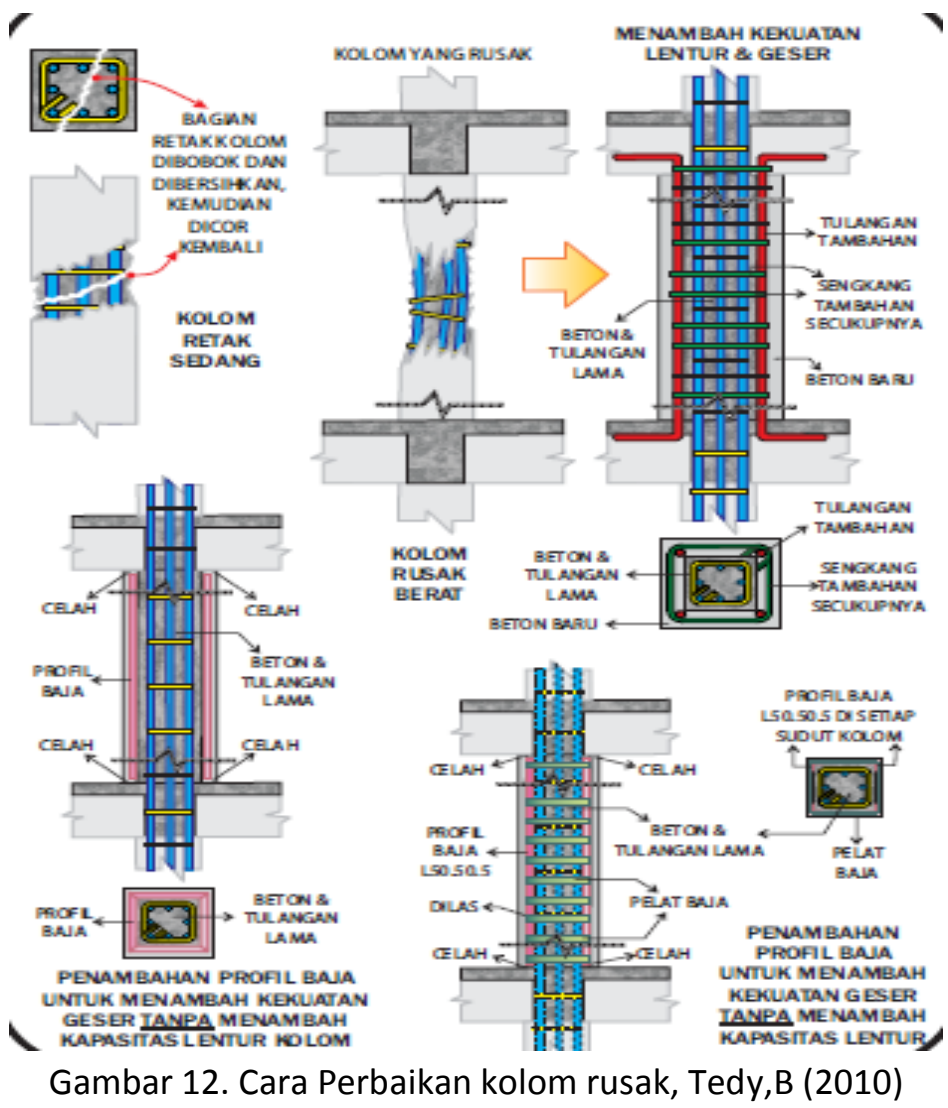




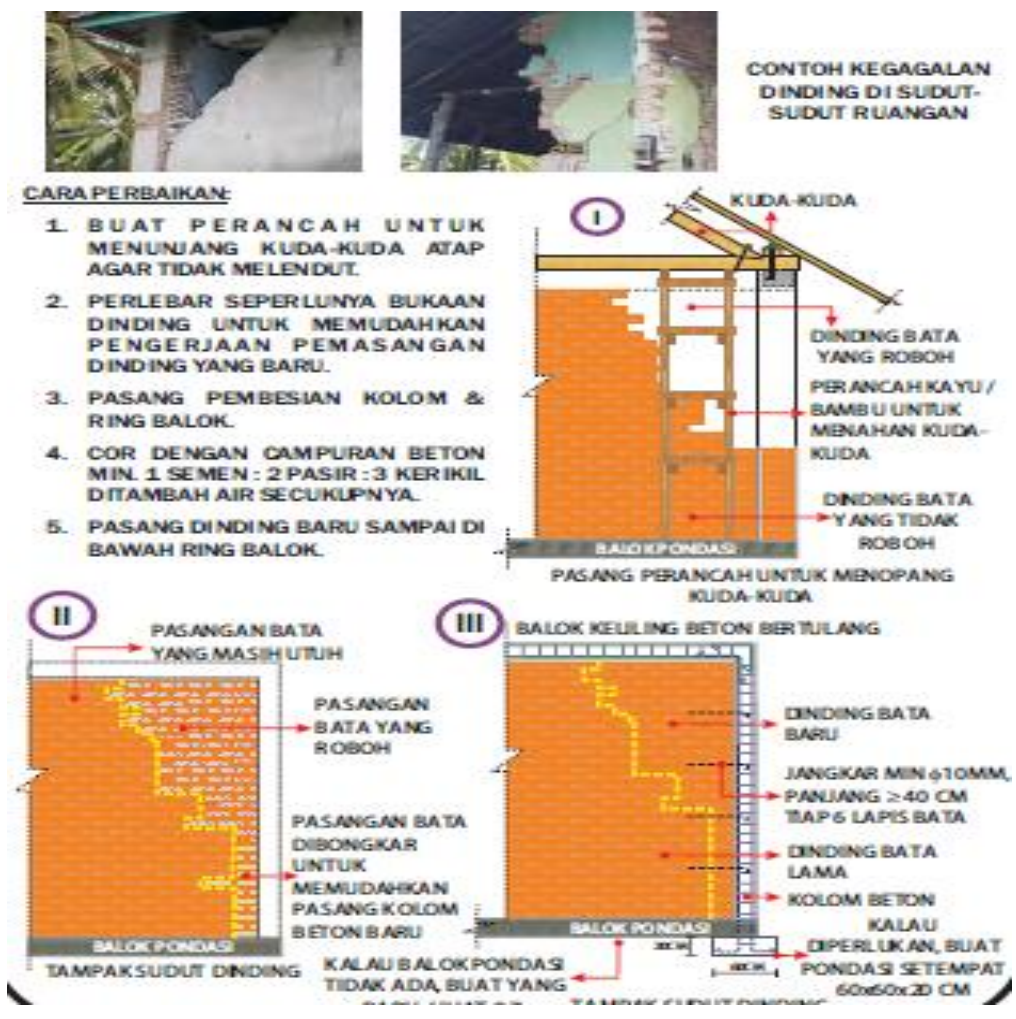

Gambar 13. Cara Pebaikan dinding rusak, Tedy,B (2010)

\section{KESIMPULAN DAN SARAN}

Pengabdian ini berjalan lancar yang berjudul Penyuluhan Bangunan Tahan Gempa Dan Metode Perbaikan Bangunan Akibat Gempa Di Pulau Lombok, dan pemilihan lokasi di desa Sedau, kecamatan Narmada, Kabupaten Lombok Barat, dan desa Gelora Kecamatan Sikur Kabupaten Lombok Timur.

$$
\text { Semoga pengabdian selanjut }
$$
mengarahkan masyarakat untuk mengurus Izin mendirikan bangunan (IMB) sebelum mendirikan bangunan karena persyaratan IMB adalah detail dan Analisa yang mau dibangun sesuai dengan syarat bangunan tahan gempa

\section{UCAPAN TERIMA KASIH}

Kami dari tim Pengabdian Fakultas teknik Jurusan Teknik Sipil Universitas Mataram, mengucapkan terima kasih yang sebesar besarnya kepada adik adik mahasiswa KKN Universitas Mataram, Dinas Pekerjaan Umum, Dinas Sosial, babinsa, Kepala Desa serta warga desa Sedau, kecamatan Narmada, Kabupaten Lombok Barat, serta warga desa Gelora Kecamatan Sikur Kabupaten Lombok Timur

\section{DAFTAR PUSTAKA}

Badan Standarisasi Nasional (2019), Persyaratan Beton Struktural Untuk Bangunan Gedung dan Penjelasannya, SNI 2847-2019

Direktorat Cipta Karya (2006), Pedoman Teknis Bangunan Tahan Gempa, Jakarta

Gideon, K (1993) Pedoman Pengerjaan Beton, Erlangga Jakarta

Gunawan, T., Margaret, (2001), Perencanaan Struktur Tahan Gempa, Delta Teknik, Jakarta 
Irsyam ,(2009), Dinamika Tanah dan Rekayasa Gempa, ITB, Bandung

Mander, J.B., Priesly, M.J.N, Park, R (1988) Theorical stress-strain model for confined, Journal of Structural Enginering ASCE

Purwono, R., (2005), Perencanaan Struktur Beton Bertulang Tahan Gempa : Perencanaan dan Perhitungan Sesuai SNI 1726 dan SNI 2847 terbaru, ITS Press, Surabaya
Purwono, R., (2007), Evaluasi Cepat Sistem Rangka Pemikul Momen Tahan Gempa, ITS Press, Surabaya

Saatcioglu, Ozcebe (1986), Confinement of Concrete Columns for Seismic Loading, ACI Structural Journal

Tedy, B (2010) Cara Memperbaiki Bangunan Sederhana Yang Rusak Akibat Gempa Bumi, Jakarta 